\title{
WYNDHAM LEWIS AND THE MEANINGS OF SPAIN
}

\author{
Alan MunTon \\ University of Plymouth
}

\begin{abstract}
Wyndham Lewis (1882-1957) visited Spain at least five times. The impact of these visits on his work was very significant. His novel The Revenge for Love (1937) is partly set in Spain, and is an important political novel of the 1930s; his painting The Siege of Barcelona (1936-37) is a significant statement about Spanish history and the Civil War. Less happy is the polemical essay Count Your Dead: They are Alive! (1937), which takes sides against the legitimate government. (He changed his mind the following year.) This discussion is based on themes apparent in Lewis's understanding of Spain: his experience at the centre and on the margins; his overcoming of well-known clichés about Spain; his grasp of the importance of Spanish Anarchism; his recognition of the gaze or mirada as an element in life; and a final discussion of The Siege of Barcelona which after 1939 was renamed The Surrender of Barcelona. That significant change indicates the seriousness of Lewis's understanding of Spain.
\end{abstract}

\section{MADRID, VIGO: CENTRE AND PERIPHERY}

It is a characteristic of Wyndham Lewis's representation of himself in his autobiographies that certain matters of importance receive less attention than they deserve. About his visits to Spain in 1903 and 1908 he has exactly nothing to say in Rude Assignment, the narrative of his career published in 1950, but it is not unreasonable to infer from this silence that his experience there was far more significant to his intellectual development than he was ready to admit. Lewis was capable of generating a great deal of meaning from very limited experience, and this is what he does with Spain. Spain affects both his art and his writing from the beginning to the very end of his career. There is the early period, with Spanish themes appearing in both the fiction and the art between 1910 and 1914; there 
are revisions in the early- and mid-1920s, there are new developments in the 1930s, centring upon the Spanish Civil War, the pre-Civil War novel The Revenge for Love (1937), and the painting The Surrender of Barcelona (1936-7?); and Spain makes a last, ghostly, appearance in Lewis's final work of fiction, "Twentieth Century Palette", the strange, incoherent and semi-realized work, probably from 1955, and written less than two years before his death in 1957.

Lewis visited Spain at least five times. The first visits were in 1903 and 1908. His next was in September 1926, when - according to Jeffrey Meyers, who offers no sources - he was "detained by martial law for three days while travelling in Spain at the time of the unsuccessful artillery revolt against Primo de Rivera in September 1926" (Meyers 1980: 131). Nothing more is known about this incident. In 1931 he arrived in Alicante by sea from Marseille on his way to Morocco, where to his regret he failed to reach the Spanish-run Rio de Oro (Lewis 1932: ix). In July 1934 he visited the French Pyrénées for a holiday after illness, and may have made his way to Puigcerda, which is mentioned in his novel of Spain, The Revenge for Love of 1937 (Meyers 1980: 221). He visited Barcelona, but it is not known exactly when.

Of these visits, the two earliest were the more important, because they were formative. The first was to the centre, Madrid, and his second to Vigo, at the decentred margins. In late August 1903 he travelled with the painter Spencer Gore to Madrid, where they stayed until mid- or late October. He was aged twenty, it was his first time abroad without his mother, and the two young artists stayed at a pensión run by an Englishwoman. They sketched from the model (paying three pesetas for three hours), and explored the Prado, where Lewis admired and copied the work of Goya. Apart from hiring artists' materials, Lewis and Gore seem to have engaged very little with the daily life of the city; and Lewis wrote to his mother: "We go to bed at 10 and get up at 8 without the least variety, and spend no money outside, as there's nothing worth spending it on" (O'Keeffe 2000: 46). On his second visit, alone, in May and June 1908, Lewis entered Spain from southwest France, along the line from Bayonne, Biarritz and Hendaye, travelling by train through the Basque country to San Sebastián and then down to León and across to Vigo, just north of the Portuguese border. This visit was more sociable than the earlier one to Madrid, for it was in Vigo (probably) that Lewis contracted the gonorrhoea that was to plague him for many years. His biographer Paul O'Keeffe points out that after his return to Brittany in June, all Lewis's sexual relations were with Spanish women, and relates his discovery that on the back of a letter from the painter Augustus John he has written out all the conjugations of 
the Spanish verb to love, amar (86-87). Altogether, Lewis probably spent some fifteen to twenty weeks in Spain.

These are the years of what Lewis called his "cryptic immaturity" (Lewis 1982: 126), years of reflection without issue in writing or painting that took him to the age of twenty-seven before his first story, set in France, was published in 1909. In 1910 his fifth publication, "A Spanish Household", appeared in the June-July number of The Tramp: An Open Air Magazine, marking the entry of Spain into Lewis's work. Immature as he probably was, Lewis did notice that Galicia was distinctive, and also that the centre had contempt for the margins. This Galician guesthouse is curiously full of contemptuous Madrileños:

The natives of this country are treated by the Spaniards as the Bretons are by the French. Because of their strange dialect, a mixture of Portuguese and Spanish, their shrewdness and boorishness, they are the laughing-stock of their Castilian neighbours. (Lewis 1982: 264)

This may be a Spanish household in Vigo, but the inhabitants of Madrid are, it appears to Lewis, the true Spaniards. This is observational travel-writing, but the sentence preceding these has the psychological acuity of fiction. The servant La Flora enacts the classic defence of the marginalised: "when the Castilian boarders made fun of her speech she would let her mouth hang still more, and her eyes would become leaden with pretended stupidity to please them and as a form of coquetry" (264). The political structure of Spain was then, and remains, an issue between the regions and the centre. When Lewis writes of the Gallegos' relation to the centre (and the Bretons' to their "French" centre), he sets up a simplified version of what will become an enduring theme of his work, a recognition of the conflict between the centre and the periphery. In the 1920s this will become politicised as a recognition that the most important legacy of late nineteenth century political theory was the contest between decentralist anarchism and centralising Marxism. In the 1930s this structure becomes vulgarised when he mistakes fascism for a decentralism that will permit the artist to work in peace. Later his political thinking takes the form of an internationalism which will enclose the decentralised entity, best summarised in a formulation of the 1940s which Marshall McLuhan took from him, and which is still used today - the global village.

\section{SPAIN AS CLICHÉ}

Lewis's interpretation of Spain characteristically begins in cliché and ends in enigma. The clichés appear in three early stories, written between 1909 and 1911, and develop into something else; the greatest enigma of all occurs in the painting 
the Siege of Barcelona, completed in 1937. In the 1920s Spain is made the location of a key moment in Lewis's development of the theory of the eye. In the 1930s, Spain is the site of his most complex and subtle political novel, The Revenge for Love (1937), whilst the Spanish Civil War is the occasion for some of his more dismaying political interventions, particularly in the 1937 polemic Count Your Dead - They are Alive! Yet in 1950 Lewis traces his origins as painter and writer back only to Brittany and Paris, leaving Spain to be listed with Holland and Germany as a less important "elsewhere" (Lewis 1984: 121).

The three early stories are "Crossing the Frontier", probably written in 1909 but not published until twenty years after Lewis's death, "A Spanish Household", published in 1910, and "A Soldier of Humour", in existence by 1911, though not published until 1917. All three show that Lewis's interpretation of Spain was as important to his early formation - if not more important - as his experiences in France.

The story "Crossing the Frontier" sets up what later becomes a familiar trope, the frontier encountered and sometimes, but not always, crossed. In that story, the speaker, arriving from France, gets as far as San Sebastián. In The Revenge for Love Margot and Victor do not make it far across the Pyrenees into Spain before falling off a cliff. In "Twentieth Century Palette" there is a chapter in which San Sebastián is the objective of travel, but is not reached. In this story of the life of the twentiethcentury artist Evelyn Parke, Parke and his family are holidaying in Biarritz during the early 1950s, and it is on the road into Spain that a terrible accident occurs, taking from Parke his wife Madeleine and three of his children. The chapter is extravagantly entitled "Holocaust". As the British Consul from the imaginary Porthez puts it: "Well, it was a station wagon loaded with luggage, and conducted by several big fat [S]paniards. [...] For the heavy station wagon your car was the merest matchwood" (Lewis [1955]: 246). If Madeleine and the children did not quite make it into Spain in around 1950, in the much earlier story Lewis's alter ego in "Crossing the Frontier" certainly does so, and once there showed a notable affection for several "big fat Spaniards." His San Sebastián landlord "was a fat, energetic little man from Valladolid". As for the pronunciation of Valladolid - always a problem for English speakers - that joke turns up again in The Revenge for Love some twentyfive years later. On this earlier occasion the name of the city of the landlord's birth "came out of his mouth like the rapid twanging of the deepest chords of a cello. All his fat seemed to vibrate dully with the sound" (Lewis 1982: 205).

Lewis's fondness for clichés about the Spanish is all too apparent. In "Crossing the Frontier" we are told that "The Spaniard is very proud" (205). In "A Spanish Household" we read that "Don Ramiro was a typical Spaniard; with a fat white 
skin and disordered black hair" (260). In the first version of "Bestre" (1909) we learn that Bestre himself "is an enormously degenerate Spaniard" because "all the virilities of the Spanish character" (232) have decayed in the atmosphere of France, where he now lives. There is in Bestre an overview of what "Spanish" means: "A survival of certain characteristics of race, that I recognised as Spanish, is particularly curious in Bestre" (232). Another racial characteristic is that "Spaniards are always trying to master each other by the magnetism of their glance" (232). But perhaps the most serious outbreak of clichés concerning Spain occurs at the beginning of the short story "A Soldier of Humour". We read:

Spain is an overflow of sombreness. "Africa commences at the Pyrenees". Spain is a checkboard of Black and Goth, on which primitive gallic chivalry played its most brilliant games. At the gates of Spain the landscape gradually becomes historic with Roland. His fame dies as difficultly as the flourish of the cor de chasse [hunting horn]. It lives like a superfine antelope in the gorges of the Pyrenees, becoming more and more ethereal and gentle. Charlemagne moves Knights and Queens beneath that tree; there is something eternal and rembrandtesque about his proceedings. A stormy and threatening tide of history meets you at the frontier. (Lewis 1982: 17)

"Spain is..." suggests that Spain is already known and can be epitomised. The phrase "Africa commences at the Pyrenees" is placed between quotation marks; so that cliché can be recognised as cliché, and Lewis uses the worn language of others to legitimise his own emerging narrative of Spain.

Spain here is an invaded place, for it is Gallic chivalry that worked itself out, in a kind of game of chess, upon this troubled landscape. Behind this lies the high-cultural cliché of regard for Charlemagne and the Chanson de Roland. Yet, in a phrase that is not cliché, "the landscape gradually becomes historic with Roland". This begins to explain what Roland is doing here; for the reference, we realize, is divided between the mythical and the historical. This passage is about the eleventh century epic in which Roland, commander of the rearguard during Charlemagne's invasion of Spain in order to fight Islam in 778, was killed by the Saracens at Ronscevalles in the Pyrenees. We are told more than once in the Chanson that Rollanz (as he is here) turns towards Spain when he dies:

The count Rollanz, beneath a pine he sits,

Turning his eyes towards Spain (Song of Roland 1919, 2375-6)

- this because he has helped to conquer Spain. He looks because he owns what he looks at. 
What Lewis seems to mean by saying that the landscape becomes historic with Roland is that to enter Spain is to enter a state of mind, to have an idea of Spain whose constituents are at first predominantly mythical, so that the myth of the Chanson descends to "the ethereal and the gentle" until it disappears and is replaced by a "tide of history" conceived as a vast game of chess played out upon the peninsula. Charlemagne's supposed seven-year campaign is predictive of all those other Peninsular campaigns that a bellicose Europe was to inflict upon Spain in a history of invasion that for Lewis has acquired the dark lighting and human dignity of a Rembrandt portrait, until at the beginning of the twentieth century he himself - unarguably real - crosses the frontier into a country that is itself at last historical and real. But its reality does not lie in its past, for that was tragic; this is an invasion by a one-man army, the Soldier of Humour named KerOrr, the Lewis-surrogate who is not a man of violence, but a laughing pseudobarbarian, and a pastiche of the medieval adventurer because he brings with him a specifically modern ability, the knowledge of how to conduct a psychological battle (here, against an invasive Frenchman who pretends to be an American). In this brief opening paragraph we have moved rapidly from cliché to enigma. Lewis is using cliché; he is not subject to it.

But cliché is not abandoned. The story into which Ker-Orr enters is a cliché of typicality, for he says that "The comedy I took part in was a spanish [ sic] one, then, at once piquant and elemental" (19): these are Spanish characteristics, evidently. Yet the hero of it is a Frenchman, the Frenchman who wanted people to believe he was an American, and who - confronted in a prepared encounter with Ker-Orr's American friends - undergoes a psychological defeat at the hands of this untypically ungentlemanly Englishman. The psychological defeat has physical consequences: "My enemy pulled himself together as though the different parts of his body all wanted to leap away in different directions, and he found it all he could do to prevent such disintegration". The content of that defeat is M. de Valmore's discovery that he is no more than what he always was, a Frenchman from the Midi: "His racial instinct was undergoing the severest revolution it had yet known" (45). Yet since this is a comedy, and not the tragedy that M. de Valmore wishes it to be, this is not about anything we would now call "race". It is a comedy enacted in Spain by an Englishman who recruits three Americans to help him break up the pretensions of a Frenchman to United States citizenship. Here "racial instinct" means the attributes (mostly clichéd) of a particular country, and Lewis, as author, participates gleefully in all of them. As Pound remarked, in these pre-war years Lewis was not simply an Englishman but "is a collection of races". Quoting this remark, Paul Edwards (2000:194) comments that Pound presumably got the idea from Lewis himself. 
That Lewis might have been, amongst other things, Spanish, brings the discussion to Augustus John's 1905 portrait of Lewis, where he is represented as an inhabitant of the peninsula (Jenkins and Stephens 2004: 91). The clichés that this portrait provoked are quoted in the catalogue of the recent Gwen John and Augustus John show at Tate Britain, where Osbert Sitwell is reported as speaking of Lewis's "lean Spanish elegance", and of the "Castilian dignity" (81) of the portrait. Presumably Castilians are dignified, just as all Spaniards are proud. The placing of the eyes here is intended to represent Lewis as a visionary, his bohemian identity allowing John to work outside the decorum of fashionable portraiture, according to the Tate catalogue, so that "far-sightedness, originality and imagination" (81) are suggested. This begs the question of why a Spanish identity should have been chosen at all. "Being Spanish" is presumably included among the "collection of races" that Lewis may have thought himself to be. But it is nevertheless a chosen identity, participating in the same loose romanticism that is to be found in Augustus John's interest in Romany life. It looks backwards in that respect, and Lewis was to condemn both Romany and the inevitable linking of Spain to bullfighting - which is another cliché - when in 1914 he blasted 'GYPSY KINGS and ESPADAS' in the first Blast (Lewis 1981: 19). To feel the need to appropriate an identity from those available within the culture suggests an essential psychic instability; but it also shows that it is possible to take a playful "let's try this" attitude towards what the culture makes available. John's painting is an effort to overcome the "cryptic immaturity" of his subject by making him appear "typically Spanish", to rescue him from emptiness by turning him into a cliché.

\section{SPAIN AND ANARCHISM}

I shall return now to the story "Crossing the Frontier" as an introduction to politics in Lewis's writing. It is usual to say, with Lewis himself, that he became political as a result of the First World War, and this is true in a very substantial sense, for his reading of Marx and Proudhon during and after that war was a transformative moment. However, there are traces of an earlier politics, in which Lewis shows a consistent interest in anarchism. Anarchist theory had reached Spain by the end of the nineteenth century, as the thinking of Pierre-Joseph Proudhon was mediated in the work of Pi y Margall and many others. By the early years of the twentieth century, this theory of decentralism and syndicalism had inspired a substantial political movement amongst working people, particularly in Catalonia, but also in those other parts of Spain that did not wish to be subject to central control from Madrid. Anarchism also provided a critique of hierarchical 
structures in politics and employment, as well as the arguments that encouraged activists to act locally, for example in the drive against illiteracy.

In "Crossing the Frontier" the young Spanish man whom the narrator meets on the train appears to be an anarchist, and not only because he does not have a train ticket. It is the record of their conversation that suggests so. Lewis writes: "This young man spoke with the deliberate and argumentative intonation of his race". There is the cliché. The enigma follows: "But besides mannerisms that were essentially national, he had an air of dazed resignation and a sort of self-restraint that seemed weighing on him -a lump in his throat that made speech difficult and his gestures rather languid". In these respects he is untypical of the stereotype from which Lewis so characteristically begins. The movement away from cliché is swift; after gesture, speech:

We discussed the details of the country we were passing through and the "Ley del [de] Terrorismo" that Señor Maura had just sprung on his countrymen. He told me that if this law were passed the whole country would be in revolt the following day. (Lewis 1982: 203)

This sounds like an anarchist speaking, and not just because of the prediction of revolt, though that is part of my diagnosis. The "Ley de Terrorismo" was proposed by the conservative government of Antonio Maura in January 1908, and it was directed specifically against Anarchists (cf. Lewis 1978: [iii]). It proposed that the authorities should be able to close anarchist centres and newspapers, and deport anarchists. This was put forward because the courts were finding it difficult to prosecute offenders in the increasingly frequent anarchist disorders, but the law itself was not actually passed. Liberal opponents of the government ensured that it failed to get through the Cortes. We know that Lewis left Paris for Spain at the end of April or the very beginning of May 1908, and it is entirely plausible that he could have had such a conversation about the Terrorism Law a few months after Maura's government had proposed it, on 24 January that year.

I do not want to press too hard on this conversation, given the likelihood that Lewis's "immaturity" at this time would have meant that he had a limited understanding of politics, but this proposed law was not about actual crimes, rather about breaking up organizations, preventing free speech, and exiling politically active people. It was to be tied to an earlier law directed against violent crimes in which explosives were used; in this way political ideas and violence were to be linked, and mutually criminalised. No doubt this is what lay behind the young man's belief that the country would revolt if the law were passed. Whether the young Lewis recognised that the "Ley de Terrorismo" attempted to erase the distinction 
between action and ideas, we do not know. He certainly reached significant conclusions about their necessary separation when after the First World War he wrote that "Truth has no place in action" (Lewis 1969 [1971]:105). Although Lewis suppressed his Spanish experience in his late autobiography, he does not suppress the term "anarchist" when he speaks in Rude Assignment of "The bums, alcoholic fishermen, penniless students (generally Russians) who might have come out of the pages of [Dostoevsky's] 'The Possessed', for long my favourite company”, for these were "an anarchist material" (Lewis 1984: 125). Significantly, Lewis immediately chooses to say that "the ringmaster of this circus" of anarchist materials is Ker-Orr, that protagonist of "A Soldier of Humour" who believed he was taking part in a specifically Spanish comedy. When Lewis is off his guard, Spain and anarchism converge in significant ways.

\section{THE SPANISH GAZE}

In this alternation between images and words, let me now return to the question of the gaze. I have already quoted Lewis as saying, in cliché mode, that "Spaniards are always trying to master each other by the magnetism of their glance". The great exemplar of this is Bestre, and the story bearing his name was so important to Lewis that he published it three times. The most substantial revision takes place between printings one and two: between the 1909 version and the revision published in The Tyro in 1922, and repeated, with minor revisions in the 1927 version. In 1909 the narrator says that

A Spanish caballero had an extravagant belief in the compelling quality of his eye, of his glance: he would choose to shrivel up a subordinate, daunt a rival, coerce a wavering adherent, rather by this dumb show than by words. (Lewis 1982: 232)

By 1927 this is compellingly revised:

The Grandee's eye is terrible, and at his best is he not speechless with pride? Eyes, eyes: for defiance, for shrivelling subordinates, for courtesy, for love. A "spanish eye" might be used as we say, "Toledo blade". There, anyway, is my argument; I place on the one side Bestre's eye: on the other I isolate the Iberian eye. Bestre's grandfather, we know, was a Castilian. (Lewis 1927: 83)

There is both cliché and ingenuity here, for force is implied by aligning the Spanish eye with Toledo steel (another cliché). The eye, then, is Bestre's chosen weapon in his battles and campaigns against his enemies in Kermanac. His eye has great power: "The Eye was really Bestre's weapon [...] Excrement as well as 
sputum would be shot from this luminous hole [...] Every resource of metonymy, bloody mind transfusion or irony were also his" (83). He is the complete satirist, and he owes it to his Spanish origins. In Spain, our narrator explains, the eye is particularly developed, for otherwise the Spanish could scarcely get through life at all. For example, "The spanish beauty imprisoned behind her casement can only roll her eyes at her lover in the street below" (83). So it is that "Bestre in his kitchen, behind his casement, was unconsciously employing this gift from his semi-arabian past" (83). Notice too the non-clichéd development, that it is the female attributes of the mirada, or glance, that Bestre has inherited. A crucial concept in Lewis - the critical eye - originates in his persistent re-imagining of a cliché about Spain.

\section{5. "AN ANARCHIST AT BOTTOM" - AND A CHANGE OF MIND}

I have already indicated that the postwar Lewis of the 1920s set up an opposition between centralising Marxism and decentralising anarchist theory. In The Revenge for Love, Lewis's novel of the pre-Civil War years which so many readers think is about the Civil War itself, we find a version of this conflict. The novel's political protagonist, the Communist Percy Hardcaster, is in hospital with the argumentative Virgilio, a Basque from Bilbao - again northern Spain, again a national grouping - whose politics are such that Percy eventually tells him that he is "at bottom" an anarchist:

"You are an Anarchist at bottom, Virgilio", said Percy at last in a palpably lame counter-attack. "That is what you are. It is the old, old Spanish difficulty - you can never get away from it. The Spaniard spoils his socialism with his anarchism". (Lewis 1991: 58)

It is a magnificent generalisation, and one by which Lewis makes comedy out of the differences between Communists and Anarchists that so significantly destabilised the Republican side during the subsequent Civil War. There is less of the eye in this novel than one would expect, but there is a reason for that. The Revenge for Love is about what is false, what is not quite right, what is faked or forged, whether paintings or politics. The eye, in Lewis's version of it, has the power to find out the truth, and there are no truths in this novel to be discovered. When the wounded Percy looks up from the ground, "right eye uppermost", at Don Alvaro, who has just shot him in the leg as he tries to escape, "he saw what he had never seen before. He saw that this man was false. His moustache was stuck on...!" (50). Falsity is the only truth to be discovered here. 
In Count Your Dead, Lewis engages ironically with the Spanish Civil War in a commentary so painful to read that I have difficulty in discussing it. The book is the supposed "thoughts" of a London clubman called Launcelot Nidwit, who is presented as the Fool who speaks Truth. In fact he speaks in the clichés appropriate to his character, and never transcends or sufficiently alters them, as Lewis was able (at his best) to alter so many others. It is only at the very end of the book that he utters a plea against the world war which, from the vantage-point of 1937 , he sees is coming:

I can see all the dead, each body with its group of mourners. I would like to say to these bereaved and helpless masses now... Count your dead! I would take each one aside and shout: They are alive! Can't you see that they are not dead yet-though people are preparing to butcher them in millions. (Lewis 1937: 358)

But this moving conclusion does not justify what goes before. It is as if Lewis knows what is going on, but cannot permit himself believe it. At one point he asks: "Do the British Government secretly desire a Franco victory?" (56), which of course the government did, and not so secretly either: but Lewis writes that Stanley Baldwin and Anthony Eden "have in fact gone in with Communism, in order that Communism should protect them against Fascism" (58). Lewis - or Nidwit, it hardly matters - cannot even accept the legitimacy of the elected Republican government in Spain (113). These contortions are made necessary by Lewis's need to show that every kind of politics - democratic, fascist, communist is finally a racket "having for guiding principle the philosophy of Force" (354). The only bearable thing about this book is that within a year of publishing it, Lewis had comprehensively changed his mind about the equal status that he here attributes to democracy and fascism.

\section{THE SIEGE OF BARCELONA}

I come finally to the visual representation of Spain in the late 1930s in a remarkable painting, first entitled The Siege of Barcelona, and later - after the fall of Barcelona in January 1939 - The Surrender of Barcelona (Michel pl. IV, [37]; MP61). This painting was not initially about contemporary Spain. Lewis said of it: "I set out to paint a Fourteenth Century [i.e., fifteenth-century] scene as I should do it could I be transported there, without too great a change in the time adjustment involved" (Lewis 1984: 140). Following upon Richard Humphrey's identification of Lewis's source as being William H. Prescott's History of the Reign of Ferdinand and Isabella the Catholic, first published in 1837, there has been agreement that the painting should be read with a double focus, in that it is about 
both the Spanish Civil War of 1936-39 and the siege of Barcelona in 1472, when the city was starved into submission and entered by the troops of John II of Aragón. Barcelona surrendered again in January 1939; whereupon Lewis changed the title of his painting from Siege to Surrender. As Paul Edwards (1998: 150) writes, Lewis's understanding was that "what is happening now in Europe and in Spain has happened before". Andrew Causey (1998: 157) concurs, arguing that consequently "the canvas should be seen as allegorical".

The work is by no means easy to interpret. It is certainly enigmatic, but it is also indeterminate, perhaps purposively so, and Causey's remark that the painting "creates mosaics of form that give different areas of the picture their own distinctness, denying naturalism" (158) is a valuable guide. One such mosaic area is at the mid-lower right, where the rear part of a horse, with its armoured rider, can be seen about to disappear behind a banner. Prescott (n.d.[1837]: 77) quotes a contemporary source as saying that the king "made his entrance into the city by the gate of St. Antony, mounted on a white charger'". One does not have to insist too much upon direct parallels to see this as a representation of power, or its effects, as are other parts of the mosaic: the hanged man in the centre, the frieze of soldiers in the foreground, the soldiers infiltrating the streets. By the time the work is retitled in 1939 Lewis has changed his political position with regard to the Republican side in the Civil War. He writes in Wyndham Lewis the Artist: From 'Blast' to Burlington House that now "the Catalan sun sets - in human blood, alas! As Barcelona falls, and the phalangist standard is unfurled there, we can all see that it is the end of a chapter - of painting, among other things". By that last remark Lewis means that no more Spanish painters, such as Picasso, Dalí or Miró would travel to Paris to radicalise European art: "There will be no more Catalan painters, to act as hormones to the old Paris cocotte" (Michel and Fox 1969 [1971]: 307).

Andrew Causey (1998: 169) has argued that the painting is an allegory of power, "an orderly picture expressing the calm imposition of order", and emblematic in complex ways. He shows too that Lewis may have represented himself seated at an easel at the centre of the central tower, and stresses the symbolic significance of the many banners and circular devices. Indeed, the work is so visually complex that "orderly" does not seem quite right. There is so much going on, and so much that is enigmatic, or resistant to interpretation, that the picture can create in the mind of the observer a sense of interpretative anxiety. I can perhaps add to this anxiety by proposing that the scene is calm because it shows the peculiar atmosphere that arises the day after the fall of a city. It shows neither a siege, nor a surrender.

The Surrender of Barcelona is Lewis's first substantial reference to eastern Spain, and to Catalunya in particular (though there are passing remarks in the 
political books of the period). During the Civil War, if you wanted to go to the occupied rebel areas, you took the route thorough Biarritz and Hendaye to San Sebastián and then south to Burgos and Salamanca; but if you wanted to volunteer, for example, to join the Republican forces, then you entered at the western end of the Pyrénées, passing through Perpignan and Port Bou, and then south to Barcelona. Lewis has arrived, at last, on the politically and artistically significant other side of Spain. He has in fact arrived in radical Spain, in the Catalunya that is radical in culture, politics and art: the Spain of Picasso, Dali and Miró, indeed of Spanish anarchism. It is a question of neither Madrid nor Vigo, but of a decentred radicalism. This brings me back to the structural device shaping the present discussion. The Surrender of Barcelona has none of the attributes of cliché, that is very obvious; nor can it be attached unequivocally to Lewis's bad politics of the 1930s. This painting resists interpretation, and gains its interest and its force from being thoroughly enigmatic.

\section{CONCLUSION}

Out of five brief visits to Spain as a young man, Lewis generated some of the most important of his strategies of painting and writing. It was the first place in which he was an outsider, forced to be objective, whether isolated with Spencer Gore in Madrid, or alone and learning to socialize in Vigo. Lewis's detachment originated here, in the kitchen at Doña Elvira's in the Calle Real, watching La Flora striking her mouth in dismay at the arrest of a young man who may or may not have been an anarchist. This was a kind of political initiation, to which reading the work of Pierre-Joseph Proudhon would later add substance. France and its culture was finally more important than Spain, but Spain came first: Lewis never forgot the Goya he encountered in Madrid in 1903, and later Los Desastres de la Guerra played a part in legitimating the post-war pacifism which caused him to try to take a "detached" or impartial view of German right-wing politics in the 1930s, thereby provoking a typically convoluted disaster of his own. In his writing, Lewis begins with cliché, but somehow transmutes the cheap assumptions of thoughtless nationalism into something complex and challenging, as he does in "A Soldier of Humour". I have characterized the outcome of some of Lewis's strategies, in writing and in painting, as enigmatic, thereby seeming to risk a cliché of my own. It is perhaps necessary to insist that I do not myself find Spain in the twentieth century (or indeed in the twenty-first) to be in any way enigmatic. I am saying that Lewis found it so, and that the more indeterminate and puzzling he represented it as being, the better truth he was telling. 


\section{REFERENCES}

Causey, Andrew. 1998. "Wyndham Lewis and history painting in the later 1930s." Wyndham Lewis and the art of modern war. Ed. David Peters Corbett. Cambridge: Cambridge University Press. 155-180.

Edwards, Paul. 1998. "It's time for another war': the historical unconscious and the failure of modernism." Wyndham Lewis and the art of modern war. Ed. David Peters Corbett. Cambridge: Cambridge University Press. 124-153.

Edwards, Paul. 2000. Wyndham Lewis: Painter and Writer. New Haven CT and London: Yale University Press.

Jenkins, David Fraser and Chris Stephens, eds. 2004. Gwen John and Augustus Jobn. London: Tate Publishing.

Lewis, Wyndham. 1910. "A Spanish Household”. The Tramp: An Open Air Magazine (June-July): 356-360.

Lewis, Wyndham. 1932. Filibusters in Barbary. New York: National Travel Club.

Lewis, Wyndham. [1955]. "Twentieth Century Palette". Unpublished typescript.

Lewis, Wyndham. 1969 [1971]. Wyndham Lewis on Art: Collected writings 19131956. Eds. Walter Michel and C. J. Fox. London: Thames and Hudson.

Lewis, Wyndham. Crossing the Frontier. Introd. B. Lafourcade and B. Morrow. Santa Barbara CA: Black Sparrow Press.

Lewis, Wyndham. 1981 (1914). Blast 1. Ed. Bradford Morrow. Santa Barbara CA: Black Sparrow Press.

Lewis, Wyndham. 1984 (1950). Rude Assignment: An Intellectual Autobiography. Ed. Toby Foshay. Santa Barbara CA: Black Sparrow Press. First published as: Rude Assignment: A narrative of my career up-to-date.

Lewis, Wyndham. 1991 (1937). The Revenge for Love. Ed. Reed Way Dasenbrock. Santa Rosa CA: Black Sparrow Press.

Lewis, Wyndham. 1992. The Complete Wild Body. Ed. Bernard Lafourcade. Santa Barbara CA: Black Sparrow Press.

Meyers, Jeffrey. 1980. The Enemy: A Biography of Wyndham Lewis. London: Routledge.

Michel, Walter. 1971. Wyndham Lewis: Paintings and Drawings. London: Thames and Hudson.

O'Keeffe, Paul. 2000. Some Sort of Genius: A Life of Wyndham Lewis. London: Cape.

Prescott, William H. N.d. [ca. 1894] (1837). History of the Reign of Ferdinand and Isabella the Catholic. Ed. John Foster Kirk. London: Swan Sonnenschein.

Song of Roland. 1919. Trans C. K. Scott Moncrieff. At http://omacl.org/Roland/r162233.html. 